\title{
The influence of excessive solar heat gains on heat loss in the hot water tank - case study
}

ABSTRACT: The analysis of a solar installation operation was conducted on the example of a detached house in the Lesser Poland province in Poland. A gas boiler and three flat-plate collectors are located inside the house, which are used for heating water in the hot water tank with a volume of $220 \mathrm{dm}^{3}$. The installation was established in 2012 . The heat measured system (for solar gains) was added in 2014. In 2015-2019 solar heat gains measured per area of absorber were higher than $340 \mathrm{kWh} / \mathrm{m}^{2}$. During a two-week period in June 2015, the insolation on the horizontal plane and the temperature were measured in 4 different points of the hot water tank. On this basis, heat losses from the storage tank were determined, i.e. a decrease in temperature during periods with and without the consumption of hot water by the residents. During this period, a temperature higher than $80^{\circ} \mathrm{C}$ was observed several times in the hot water tank. In two parts of the hot water tank, rhe determined temperature decreases were used to obtain the heat loss amount. In the analyzed period ( 2 weeks), 9 days were observed with solar heat gains higher than $9 \mathrm{kWh} /$ day. For these days, the value of heat loss from the solar hot water tank was estimated at over $6 \mathrm{kWh} /$ day. This data corresponds to the actual heat demand for hot water preparation in the building at $7.3 \mathrm{kWh} /$ day. The correlation between daily solar heat gains and solar hot water tank heat losses were also determined. In addition, based on the amount of heat losses, the value of the

$\triangle$ Corresponding Author: Piotr Olczak; e-mail: olczak@min-pan.krakow.pl

1 Mineral and Energy Economy Research Institute of the Polish Academy of Sciences, Kraków, Poland; ORCID iD: 0000-0002-4926-0845; e-mail: olczak@min-pan.krakow.pl

2020. The Author(s). This is an open-access article distributed under the terms of the Creative Commons Attribution-ShareAlike International License (CC BY-SA 4.0, http://creativecommons.org/licenses/by-sa/4.0/), which permits use, distribution, and reproduction in any medium, provided that the Article is properly cited. 
tank loss coefficient was estimated. The obtained value was compared with the manufacturer's data and reference data.

KEYwORDS: renewable energy, solar energy, flat plate collector, hot water tank, tank loss coefficient

\section{Introduction}

At present, the increase in renewable energy production can be observed in Poland (Piwowar and Dzikuć 2019). This fact, along with the growth of social awareness of using environmental friendly technologies (Hansen et al. 2019; Smol et al. 2018) improves i.e. air quality (Jeleński et al. 2020; Kryzia and Pepłowska 2019). In Poland, not only does the typical use of renewable energy equipment such as wind energy turbines (Chmielniak 2019; Sornek et al. 2017), photovoltaic (Żołądek et al. 2019), photovoltaic/thermal (Calise et al. 2019; Olczak et al. 2020b), solar thermal collectors (Chwieduk 2010), biomass boilers (Drobnik et al. 2019) contribute to improving the environment, but gas cogeneration (Matuszewska et al. 2017; Szurlej et al. 2014) and clean coal technologies also contribute (Kryzia et al. 2016).

The article is limited to the use of solar energy, namely flat solar collectors, in which the correct selection of the absorber area is important to maximize the effect of the solar installation (Olczak et al. 2020a; Olek et al. 2016). In the case in which the size of the installation is small, its productivity can be increased by, for example, using mirrors (Baccoli et al. 2018) of the rack (Olczak et al. 2016) setting the angle of inclination at different times of the year (Olczak et al. 2018), trackers and others (Figaj et al. 2019). In turn, excess solar energy can be accumulated in a Phase Change Material tank (Kuta et al. 2016), concrete accumulator (Sacharczuk and Taler 2019), Thermo-Electric Energy Storage (Fiaschi et al. 2019) or used in installations with Organic Rankine Cycle (Freeman et al. 2015; Matuszewska et al. 2014). The article examined the real case of solar thermal installation for a detached house in Lesser Poland (Fig. 1) in order to show the impact of excessive daily heat energy productivity by flat plate collectors in relation to daily energy consumed and the amount of heat losses from the hot water tank. This happens when the water in the tank heats up to a temperature higher than required for hot water (in Poland it is $55^{\circ} \mathrm{C}$ (Ministry of Development 2015)). 


\section{Description of the installation in the detached house (domestic hot water)}

The solar thermal system consists of 3 Biawar Sirius Plus flat collectors (placed on the roof of the building, absorber area $\left.=5.61 \mathrm{~m}^{2}\right)$, solar hot water tank with a capacity $\left(V_{h w t}\right)$ of $210 \mathrm{dm}^{3}$ (Fig. 1), pumping system, insulated piping and solar controller. The pipeline between the collectors and the lower coil of the solar storage tank is surrounded by a protective tube which runs through unused flue and joins the attic of the building with the storage tank room. The upper coil of the storage tank is heated by a domestic gas fired boiler. The cold water comes either from the hydrophore (the primary source) or from the water supply (the backup source).

For this house, the value of heat demand for producing hot water is $7.3 \mathrm{kWh}$ /day (Olczak et al. 2015). The measured solar heat gains are depicted in Figure 2 (daily results) and Figure 3 (yearly results).

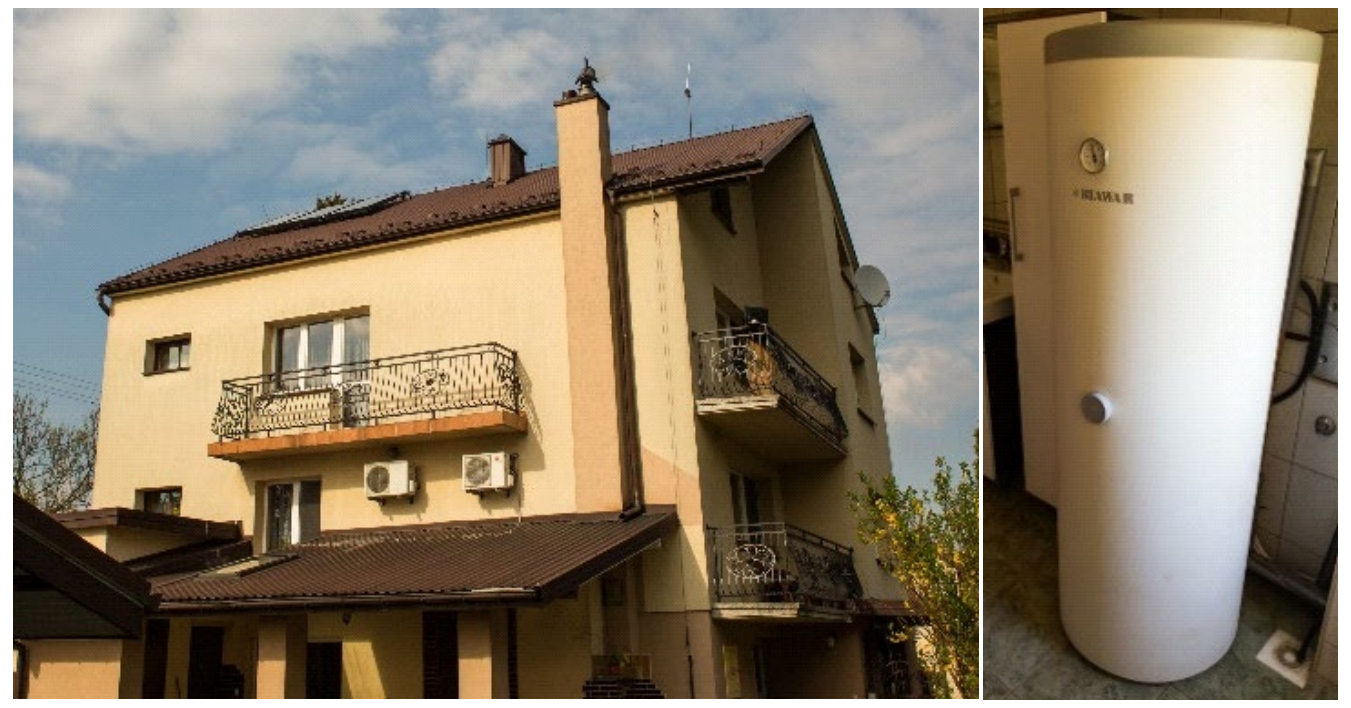

Fig. 1. The detached house and the solar storage tank inside Source: own study

Rys. 1. Budynek i zasobnik solarny 


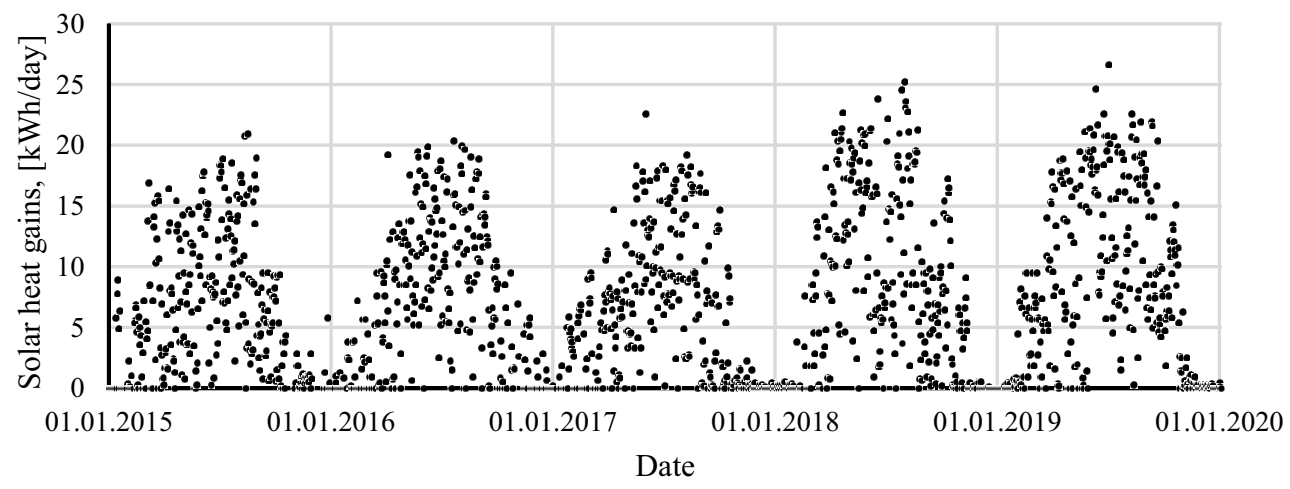

Fig. 2. Measured daily solar heat gains in installation Source: own study

Rys. 2. Zmierzone dzienne uzyski solarne w instalacji

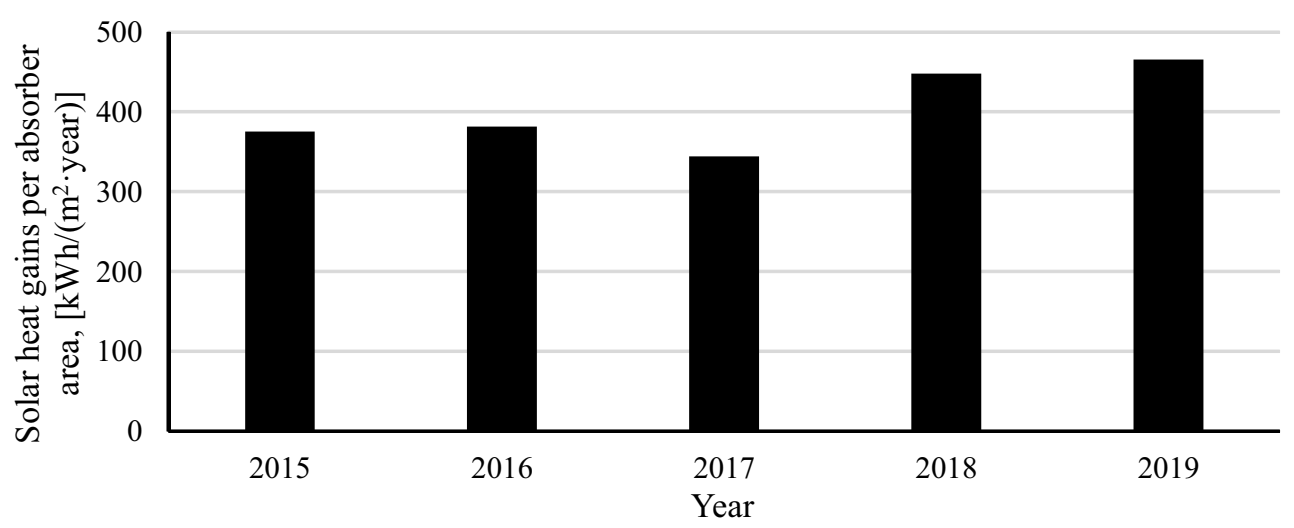

Fig. 3. Measured yearly solar heat gains in installation per absorber area

Source: own study

Rys. 3. Zmierzone roczne uzyski solarne w instalacji przeliczone na powierzchnię absorbera

\section{Measurement system}

The study was conducted in the period of June 2015 with the use of the following devices:

$\checkmark$ BIAWAR solar controller (type PLUM) with the heat meter (one of the basic solar system components),

$\downarrow$ thermistors joined with the PLUM solar controller, 
$\checkmark$ thermocouples (meter type PROVA 800), serving the designation of the temperature at different points of the installation (Fig. 4). Basic accuracy $0.1 \% \pm 1^{\circ} \mathrm{C}$ (PROVA 2020),

$\checkmark$ EPLAB pyranometer (Eplab), accuracy class (2\%) (EPLAB 2015).

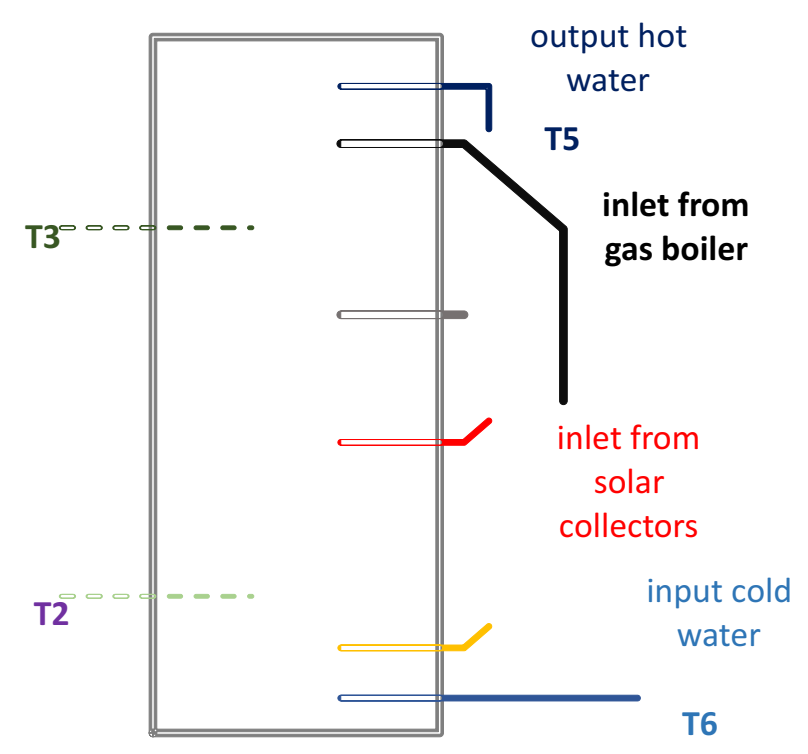

Fig. 4. Placement of the sensors (thermocouples T2, T3, T5, T6) in the hot water tank Source: own study

Rys. 4. Umiejscowienie czujników temperatury (T2, T3, T4, T5, T6) w zasobniku ciepłej wody użytkowej

\section{Methodology and results}

During the test, the temperature was measured at 5 interesting points (selected out of 8) recorded by PROVA 800 and presented in Figure 5. Due to the T5 sensor installation place (point - Fig. 4) and the condition that was always fulfilled in the analyzed period of 16 days (T5 $>$ ambient temperature), when hot water was taken from the hot water tank, this occurred due to a temperature increase (T5). When the next condition is fulfilled (T3>T5) the lack of water intake results in a temperature decrease observed at $\mathrm{T} 5$. 


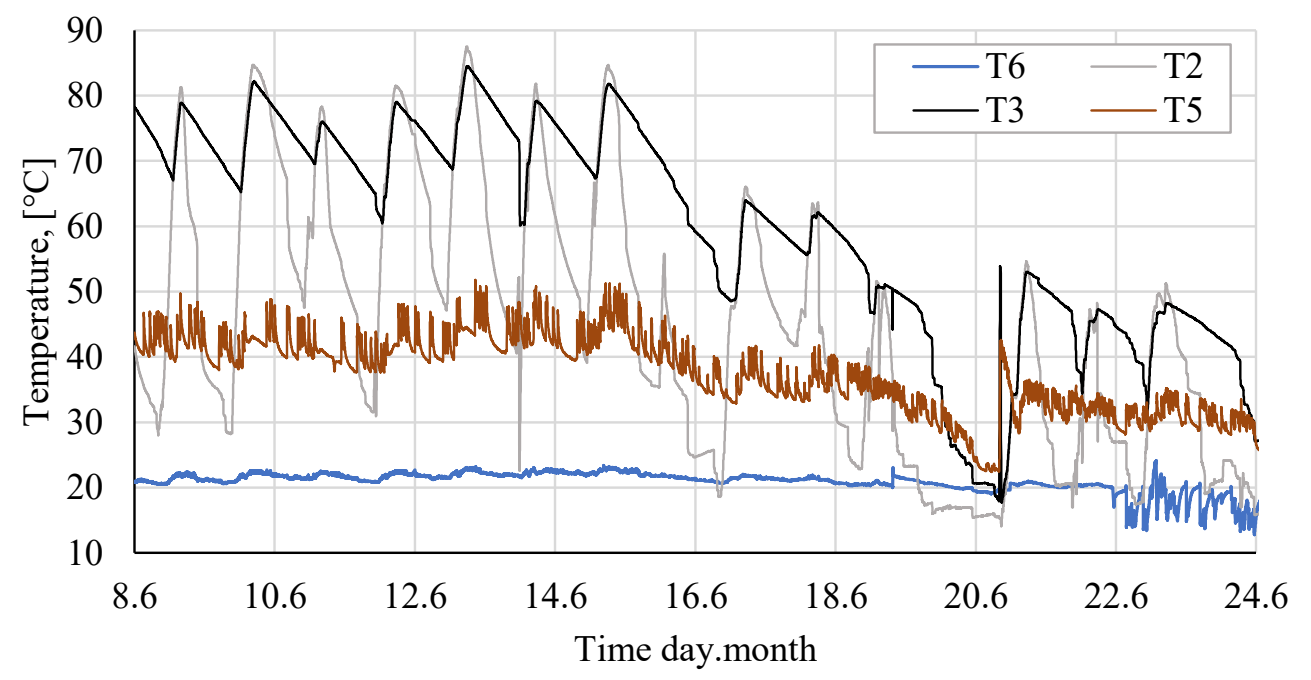

Fig. 5. The temperature measurements from June 8-24, 2015

Source: own study

Rys. 5. Pomiary temperatury w okresie 8.06.2015-24.06.2015

For further analysis, a number of time periods were chosen. The chosen periods included only those during which hot water wasn't used for at least one hour, which took place usually at night. To visualize the outcome of these actions the chosen time periods were presented in Figure 6 as a function of the onset temperature and the duration time of each chosen time period.

Different slopes of the curves are connected with various external conditions in the boiler room and the temperature stratification in the hot water tank.

In the next stage, the observed temperature decreases were grouped to obtain the values of the temperature drop per minute. Finally, the linear regression function for the obtained results was calculated. The results for the upper and lower part of the hot water tank were shown separately in Figure 7.

The regression functions (red and red dashed line - Fig. 7) were allowed to determine the equation for the temperature decrease function depending on the temperature in two parts of the hot water tank: the upper part (up) of the hot water tank - eq. 1. $\left(R^{2}=0.91\right)$ and the lower part $(l p)$ of the hot water tank - eq. $2\left(R^{2}=0.62\right)$.

$$
\begin{aligned}
& \Delta T 3 u p(T 3)=0.000185 \cdot T 3-0.003[\mathrm{~K} / \mathrm{min}] \\
& \Delta T 2 \operatorname{lp}(T 2)=0.000544 \cdot T 2-0.004[\mathrm{~K} / \mathrm{min}]
\end{aligned}
$$

The hot water tank heat capacity and the temperatures decreases defined by equations number 1 and 2 were allowed to assess heat losses in the hot water tank per minute - eq. 3 and eq. 4 . 


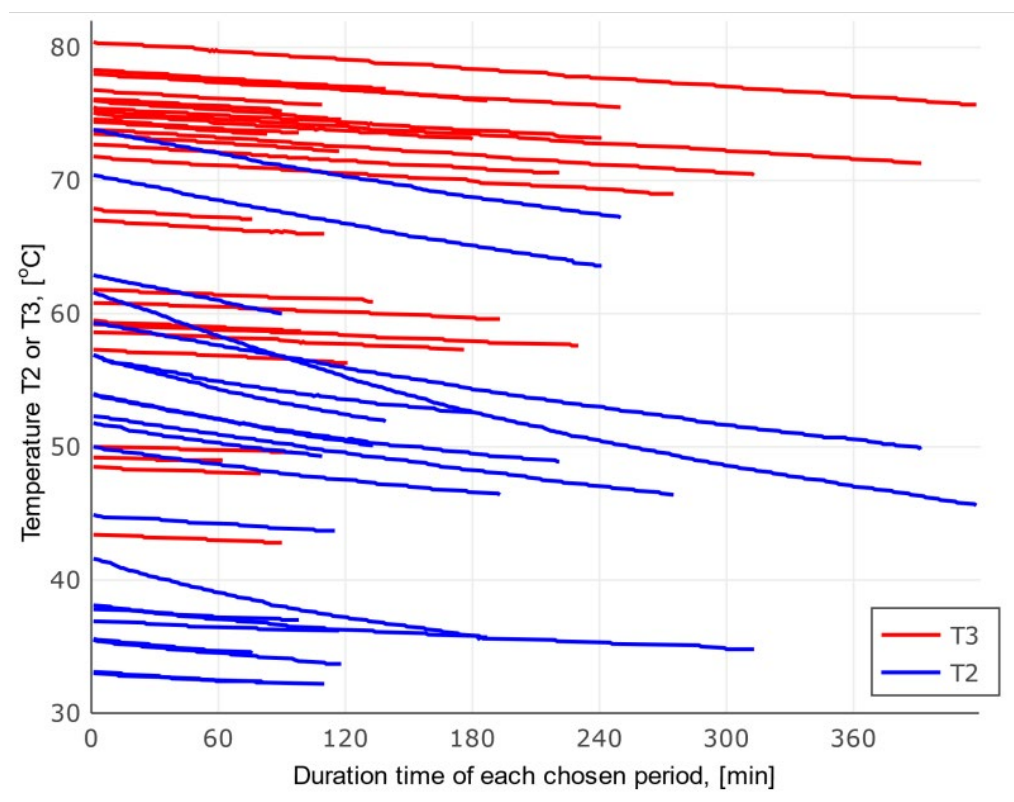

Fig. 6. The observed temperature decreases of $\mathrm{T} 3$ and $\mathrm{T} 2$ Source: own study

Rys. 6. Zaobserwowane spadki temperatury mierzonej w punkcie T3 i T2

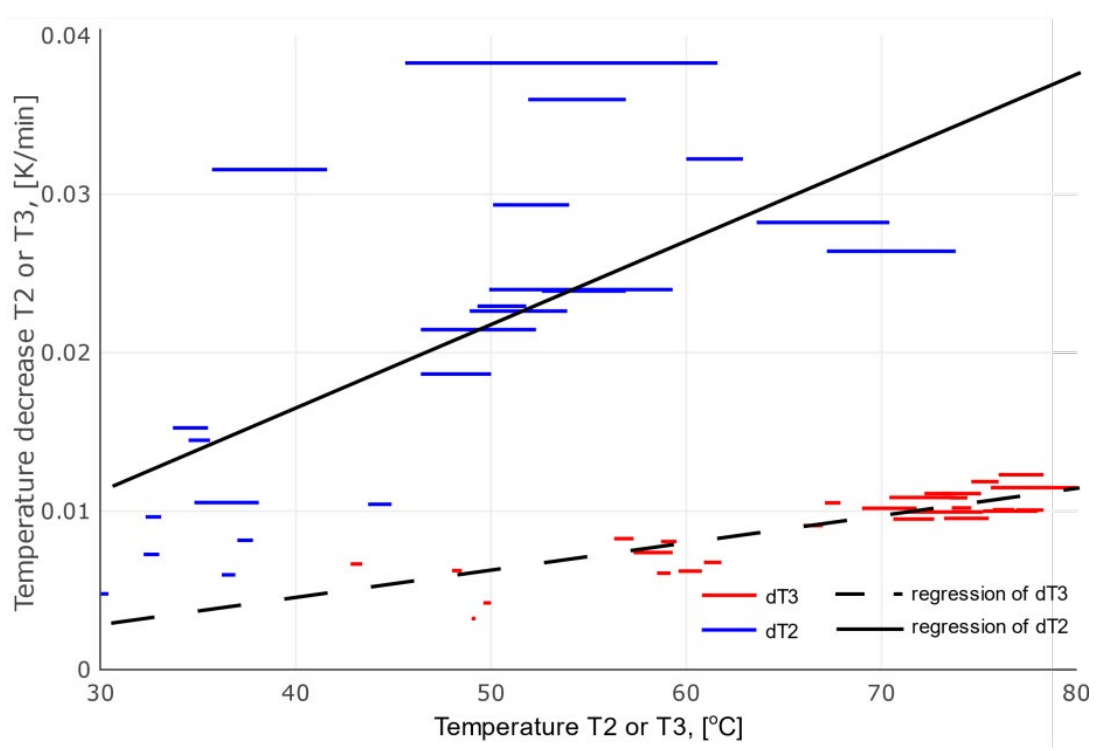

Fig. 7. Temperature decreases (dT2 and dT3) per minute presented as a present temperature function Source: own study

Rys. 7. Zarejestrowane spadki temperatury (dT2 i dT3) w ciągu minuty jako funkcja aktualnej temperatury 


$$
\begin{aligned}
& H L(T 3) \text { up }=\Delta \text { T3up } \cdot 1 / 2 \cdot V_{h w t} \cdot \rho_{\text {water }(T 3)} \cdot c_{\text {water }}[\mathrm{kJ} / \mathrm{min}] \\
& H L(T 2) l p=\Delta T 2 l p \cdot 1 / 2 \cdot V_{h w t} \cdot \rho_{\text {water }(T 2)} \cdot c_{\text {water }}[\mathrm{kJ} / \mathrm{min}]
\end{aligned}
$$

where:

$V_{h w t}=0,21 \mathrm{~m}^{3}$.

Density (Fan and Furbo 2012):

$$
\begin{gathered}
\rho_{\text {water }}(T \ldots)=863+1.21 \cdot(T \ldots)-0.00257 \cdot(T \ldots)^{2}\left[\mathrm{~kg} / \mathrm{m}^{3}\right] \\
T \ldots=T 2 \text { or } T 3+273.15[\mathrm{~K}]
\end{gathered}
$$

$c_{\text {water }}=4180 \mathrm{~J} /(\mathrm{kg} \cdot \mathrm{K})$ constant specific heat of water (Fan and Furbo 2012).

In consequence, it is possible to calculate the sum of heat losses for one day depending on $T 3$ and $T 2$ temperatures per each minute of the day:

$$
H L(T 2, T 3, \tau)=\frac{1}{3600} \sum_{\tau=1}^{1440}(H L(T 3) u p+H L(T 2) l p)[\mathrm{kWh} / \mathrm{day}]
$$

Numerical values calculated on the basis of eq. 7 and density solar radiation, insolation for collector area and solar energy heat gains are shown in Figure 8.

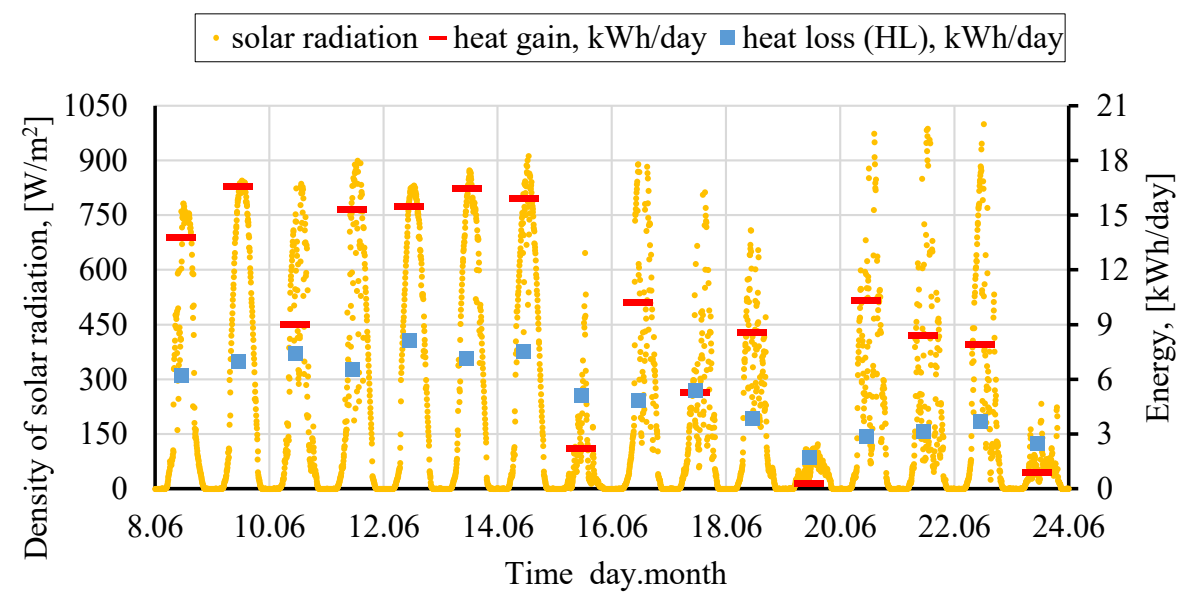

Fig. 8. Comparison between solar radiation density, measured solar heat gains (energy) and assessed heat losses from the hot water tank (energy)

Source: own study

Rys. 8. Porównanie pomiędzy: natężeniem promieniowania słonecznego, zmierzonymi solarnymi uzyskami ciepła oraz stratami ciepła z zasobnika

98 
The correlation between the daily amount of heat losses and daily sum of solar heat gains was analyzed was calculated, and it is 0.76 . The obtained value of the correlation coefficient was diminished by the occurrence of the time shift between heat gains and losses.

As a result of the analysis, it was possible to find the correlation between the amount of heat losses and the hot water tank temperature, which is determined by the type of the hot water tank and its location. Moreover how the solar heat gains influence the heat losses was also assessed.

Additionally, the tank loss coefficient (TLC) was calculated for temperature $T 2$ and $T 355^{\circ} \mathrm{C}$ and the temperature of the boiler room (where the hot water tank is located) $20^{\circ} \mathrm{C}$ using Eq. 8. The results are shown in Table 1. In this real case, the TLC value was more than three times higher than the value taken from the producer's data and from the reference data. This was mostly dependent on the uncertainty of heat loss assumption from the lower part of the hot water tank.

$$
T L C(T 2, T 3)=(H L(T 3) u p+H L(T 2) l p) / T D \cdot 60 \frac{\mathrm{min}}{h} / H W T S\left[\mathrm{~kJ} /\left(\mathrm{h} \cdot \mathrm{m}^{2} \cdot \mathrm{K}\right)\right]
$$

where:

HWTS - hot water tank surface, HWTS $=3.5 \mathrm{~m}^{2}$ (Biawar 2019),

$T D$ - difference between hot water tank and boiler room temperature $(35 \mathrm{~K})$.

TABLE 1. Hot water tank - results and references

TABELA 1. Zasobnik ciepłej wody - charakterystyka i wyniki

\begin{tabular}{|l|c|c|}
\hline \multicolumn{1}{|c|}{ Thermal storage - results } & Unit & Value \\
\hline Tank volume $\left(V_{h w t}\right)$ & $\mathrm{m}^{3}$ & 0.21 \\
\hline TLC $(T 2=55, T 3=55)$ & $\mathrm{kJ} /\left(\mathrm{h} \cdot \mathrm{m}^{2} \cdot \mathrm{K}\right)$ & 7.7 \\
\hline Tank Loss Coefficient $\left(\right.$ for $\left.0.3 \mathrm{~m}^{3}\right)$, Reference 3 & $\mathrm{~kJ} /\left(\mathrm{h} \cdot \mathrm{m}^{2} \cdot \mathrm{K}\right)$ & 2.5 \\
\hline Tank Loss Coefficient $\left(\right.$ for $\left.0.45 \mathrm{~m}^{3}\right)$, Reference 4 & $\mathrm{~kJ} /\left(\mathrm{h} \cdot \mathrm{m}^{2} \cdot \mathrm{K}\right)$ & 1.6 \\
\hline Heat Loss per day & $\mathrm{kWh} / \mathrm{day}$ & 6.2 \\
\hline Heat Loss & $\mathrm{W}$ & 260 \\
\hline Heat Loss, Reference 2 & $\mathrm{W}$ & 81 \\
\hline Heat Loss (producer data - Reference 1$)$ & $\mathrm{W}$ & 86 \\
\hline
\end{tabular}

Source: own study based on (Biawar 2019; En 2007; Mehdaoui et al. 2014; Sokhansefat et al. 2018).

\section{Summary}

The heat losses from solar hot water installed in a single-family house depending on solar heat gains were analyzed. As a result of the analysis, it was possible to find the correlation $(0.76)$ between heat losses and the present hot water tank temperature, which is determined by the type 
of the hot water tank and its location. How the solar heat gains influence the heat losses was also assessed. Additionally, the tank loss coefficient value $\left(7.7 \mathrm{~kJ} /\left(\mathrm{h} \cdot \mathrm{m}^{2} \cdot \mathrm{K}\right)\right.$ much higher than in reference sources) was calculated.

\section{References}

Baccoli et al. 2018 - Baccoli, R., Frattolillo, A., Mastino, C., Curreli, S. and Ghiani, E. 2018. A comprehensive optimization model for flat solar collector coupled with a flat booster bottom reflector based on an exact finite length simulation model. Energy Conversion and Management Vol. 164, pp. 482-507.

BIAWAR 2019. Vertical storage tanks. [Online] https://www.biawar.com.pl/en/produkt/mega-for-solar -systems-220-10001/ [Accessed: 2020-01-05].

Calise et al. 2019 - Calise, F., Figaj, R.D. and Vanoli, L. 2019. Energy performance of a low-cost PhotoVoltaic/Thermal (PVT) collector with and without thermal insulation. IOP Conference Series: Earth and Environmental Science Vol. 214, pp. 1-12, DOI: 10.1088/1755-1315/214/1/012116.

Chmielniak, T. 2019. Wind and solar energy technologies of hydrogen production - a review of issues. Polityka Energetyczna - Energy Policy Journal Vol. 22, Iss. 4, pp. 5-20.

Chwieduk, D. 2010. Solar energy use for thermal application in Poland. Polish Journal of Environmental Studies Vol. 19, No. 3, pp. 473-477.

Drobnik et al. 2019 - Drobnik, P., Mirowski, T. and Kopeć, A. 2019. Economic and environmental benefits from carbonized biomass use for energy purposes - Case study for the community from southern part of Poland. IOP Conference Series: Earth and Environmental Science Vol. 214, DOI: 10.1088/1755$1315 / 214 / 1 / 012106$.

European Norm, B.S. 2007. Heating systems in buildings - Method for calculation of system energy requirements and system efficiencies. Management Vol. CEN/TC 228.

EPLAB 2015. Black \& White Pyranometer. [Online] http://www.eppleylab.com/wp-content/uploads/pdf/ EPPLEY160919-8-48-Diffuse.pdf [Accessed: 2020-01-05].

FAN, J. and FURBo, S. 2012. Buoyancy driven flow in a hot water tank due to standby heat loss. Solar Energy Vol. 86, No. 11, pp. 3438-3449.

Fiaschi et al. 2019 - Fiaschi, D., Manfrida, G., Petela, K. and Talluri, L. 2019. Thermo-electric energy storage with solar heat integration: Exergy and exergo-economic analysis. Energies Vol. 12, No. 4, DOI: $10.3390 /$ en12040648.

Figaj et al. 2019 - Figaj, R., Szubel, M., PrzenzaK, E. and Filipowicz, M. 2019. Feasibility of a small-scale hybrid dish/flat-plate solar collector system as a heat source for an absorption cooling unit. Applied Thermal Engineering Vol. 163, DOI: 10.1016/j.applthermaleng.2019.114399.

Freeman et al. 2015 - Freeman, J., Hellgardt, K. and Markides, C.N. 2015. An assessment of solar-powered organic Rankine cycle systems for combined heating and power in UK domestic applications. Applied Energy Vol. 138, pp. 605-620.

Hansen et al. 2019 - Hansen, P., Liu, X. and Morrison, G.M. 2019. Agent-based modelling and sociotechnical energy transitions: A systematic literature review. Energy Research and Social Science Vol. 49, pp. 41-42.

Jeleński et al. 2020 - Jeleński, T., Dendys, M., Tomaszewska, B. and PAjĄK, L. 2020. The Potential of RES in the Reduction of Air Pollution: The SWOT Analysis of Smart Energy Management Solutions for Krakow Functional Area (KrOF). Energies Vol. 13(7), DOI: 10.3390/en13071754.

KryZia et al. 2016 - KryZia, D., Gawlik, L. and Peplowska, M. 2016. Conditions for development of clean technologies of energy generation from fossil fuels (Uwarunkowania rozwoju czystych techno-

100 
logii wytwarzania energii z paliw kopalnych). Polityka Energetyczna - Energy Policy Journal Vol. 19, Iss. 4, pp. 63-74 (in Polish).

Kryzia, D. and PePlowsKa, M. 2019. The impact of measures aimed at reducing low-stack emission in Poland on the energy efficiency and household emission of pollutants. Polityka Energetyczna - Energy Policy Journal Vol. 22, Iss. 2, pp. 121-132.

Kuta et al. 2016 - Kuta, M., Matuszewska, D. and Wóscik, T.M. 2016. The role of phase change materials for the sustainable energy. E3S Web of Conferences Vol. 10, DOI: 10.1051/ e3sconf $/ 20161000068$.

Matuszewska et al. 2017 - Matuszewska, D., KutA, M. and GóRSKi, J. 2017. Cogeneration - Development and prospect in Polish energy sector. E3S Web of Conferences Vol. 14, DOI: 10.1051/ e3sconf $/ 20171401021$.

Matuszewska et al. 2014 - Matuszewska, D., Sztekler, K. and Gorski, J. 2014. An influence of low-stability region on dense gas phenomena and their peculiarities in the ORC fluids. MATEC Web of Conferences Vol. 18, DOI: 10.1051/matecconf/20141803005.

Mehdaoui, et al. 2014 - Mehdaoui, F., Hazami, M., Naili, N. and Farhat, A. 2014. Parametric study of a solar heating system used for buldings air heating. IREC $2014-5^{\text {th }}$ International Renewable Energy Congress, pp. 1-6.

Ministry of Development 2015. Regulation of the Minister of Infrastructure and Development of 27 February 2015 on the methodology for determining the energy performance of a building or part of a building, and energy performance certificates (Rozporzadzenie Ministra Infrastruktury i Rozwoju z dnia 27 lutego 2015 r. w sprawie metodologii wyznaczania charakterystyki energetycznej budynku lub części budynku oraz świadectw charakterystyki energetycznej). Journal of Laws of the Republic of Poland. [Online] http://prawo.sejm.gov.pl/isap.nsf/download.xsp/WDU20150000376/O/D20150376.pdf [Accessed: 2020-03-22] (in Polish).

Olczak et al. 2018 - Olczak, P., Kryzia, D., Peplowska, M. and Olek, M. 2018. Influence of Inclination Angle and its Adjustment Time on Insolation of Collector or Photovoltaic Panel. District Heating Heating Ventilatio Vol. 49, No. 12, pp. 506-509.

Olczak et al. 2020a - Olczak, P., Matuszewska, D. and Zabaglo, J. 2020a. The Comparison of Solar Energy Gaining Effectiveness between Flat Plate Collectors and Evacuated Tube Collectors with Heat Pipe: Case Study. Energies Vol. 13, No. 7, DOI: 10.3390/en13071829.

OlcZAK et al. 2020b - OlcZAK, P., OleK, M. and KryZia, D. 2020b. The ecological impact of using photothermal and photovoltaic installations for DHW preparation. Polityka Energetyczna - Energy Policy Journal Vol. 23, Iss. 1, pp. 65-74.

Olczak et al. 2016 - Olczak, P., Porzuczek, J. and Kandefer, S. 2016. Passive Sun Tracking of a Single Evacuated Tube Collector with the Focusing Mirror. Proceedings of 2016 IEEE International Conference and Renewable Energy ICPRE 2016 Vol. II, IEEE, Szanghaj, pp. 611-615.

OlczaK et al. 2015 - OlczaK, P., Zabaglo, J., Kandefer, S. and Dziedzic, J. 2015. Influence of Solar Installation with Flat-Plate Collectors in a Detached House on Pollutants Emission and Waste Stream. Between Evolution and Revolution - in Search of an Energy Strategy, Poznań: WAT, pp. 739-752.

Olek et al. 2016 - Olek, M., OlczaK, P. and Kryzia, D. 2016. The sizes of Flat Plate and Evacuated Tube Collectors with Heat Pipe area as a function of the share of solar system in the heat demand. E3S Web of Conferences Vol. 10, DOI: 10.1051/e3sconf/20161000139.

Piwowar, A. and Dzikuć, M. 2019. Development of Renewable Energy Sources in the Context of Threats Resulting from Low-Altitude Emissions in Rural Areas in Poland: A Review. Energies Vol. 12, No. 18, DOI: $10.3390 /$ en12183558.

PROVA 2020. PROVA 800 Multi-Input Thermometer/Datalogger. PROVA. [Online] www.prova.com.tw/ product_detail.asp?seq=23 [Accessed: 2020-05-18]. 
SACHARCZUK, J. and TALER, D. 2019. Numerical and experimental study on the thermal performance of the concrete accumulator for solar heating systems. Energy Vol. 170, pp. 967-977.

Smol et al. 2018 - Smol, M., Avdiushchenko, A., KulcZycka, J. and NowaczeK, A. 2018. Public awareness of circular economy in southern Poland: Case of the Malopolska region. Journal of Cleaner Production Vol. 197, pp. 1035-1045.

Sokhansefat et al. 2018 - Sokhansefat, T., Kasaeian, A., Rahmani, K., Heidari, A.H., Aghakhani, F. and Mahian, O. 2018. Thermoeconomic and environmental analysis of solar flat plate and evacuated tube collectors in cold climatic conditions. Renewable Energy Vol. 115, pp. 501-508.

Sornek et al. 2017 - Sornek, K., Filipowicz, M., Goryl, W., Mokrzycki, E., Mirowski, T. and DuraCZYŃSKI, M. 2017. The analysis of the wind potential in selected locations in the southeastern Poland. E3S Web of Conferences Vol. 14, DOI: 10.1051/e3sconf/20171401014.

Szurlej et al. 2014 - Szurlej, A., Kamiński, J., JAnusz, P., Iwicki, K. and Mirowski, T. 2014. Gas-fired power generation in Poland \&amp; energy security (Rozwój energetyki gazowej w polsce a bezpieczeństwo energetyczne). Rynek Energii Vol. 6, pp. 33-38 (in Polish).

ŻolĄDeK et al. 2019 - ŻolĄDeK, M., Filipowicz, M., Sornek, K. and FigaJ, R.D. 2019. Energy performance of the photovoltaic system in urban area - Case study. IOP Conference Series: Earth and Environmental Science, DOI: 10.1088/1755-1315/214/1/012123.

Piotr OlCZAK

\section{Wpływ nadmiernych uzysków solarnych na straty ciepła z zasobnika cwu - studium przypadku}

\section{Streszczenie}

Analiza aspektów pracy instalacji solarnej została przeprowadzona na przykładzie domu jednorodzinnego w województwie małopolskim w Polsce. W analizowanym budynku jednorodzinnym znajduje się kocioł gazowy i instalacja solarna złożona z trzech płaskich kolektorów słonecznych. Urządzenia te odpowiadają za przygotowanie ciepłej wody użytkowej magazynowanej w zasobniku o pojemności $210 \mathrm{dm}^{3}$.

Instalacja powstała w 2012 roku, w 2014 roku została opomiarowana pod kątem uzysków solarnych. W latach 2015-2019 mierzono uzyski solarne, były one wyższe niż $340 \mathrm{kWh} / \mathrm{m}^{2}$ powierzchni absorbera.

Podczas dwutygodniowego okresu w czerwcu 2015 roku mierzono także natężenie promieniowania słonecznego na płaszczyźnie poziomej i temperaturę w 4 różnych punktach zasobnika ciepłej wody. Na tej podstawie określono straty ciepła z zasobnika, tj. spadek temperatury w zasobniku w okresach z i bez poboru ciepłej wody użytkowej przez mieszkańców. W tym okresie zanotowano temperaturę wyższą niż $80^{\circ} \mathrm{C}$ w zasobniku tylko przez kilka stosunkowo krótkich okresów. Wyznaczone spadki temperatury w dwóch częściach zasobnika ciepłej wody użytkowej użyto do określenia ilościowych strat ciepła. W analizowanym okresie (2 tygodnie) zaobserwowano 9 dni z uzyskami solarnymi wyższymi niż $9 \mathrm{kWh} /$ dzień. Dla tych dni oszacowano wartości strat ciepła z zasobnika na poziomie powyżej $6 \mathrm{kWh} /$ dzień. Dane te korespondują 
z rzeczywistym zapotrzebowaniem na ciepło do przygotowania ciepłej wody użytkowej w budynku na poziomie $7,3 \mathrm{kWh} /$ dzień.

Określono także zależności między dziennymi uzyskami solarnymi a stratami ciepła z zasobnika (korelacja). Ponadto bazując na wielkościowych stratach ciepła, oszacowano wielkość współczynnika strat ciepła z zasobnika. Uzyskaną wartość porównano z danymi producenta i danymi referencyjnymi.

SŁOWA KLUCZOWE: energia słoneczna, energia odnawialna, płaskie kolektory słoneczne, zasobnik ciepłej wody, współczynnik strat ciepła z zasobnika 
